\title{
Determination of Lisinopril in Pure and Tablet form by Using 2-Hydroxynaphthaldehyde as Derivatizing Reagent
}

\author{
Zahid Ali Zounr ${ }^{1}$, Ayaz Ali Memon ${ }^{2}$, Abdul Ghani Memon ${ }^{1}$, F. M. A. Rind ${ }^{1}$, \\ M. Y. Khuhawar ${ }^{3}$, Ghulam Quadir Khaskheli ${ }^{1}$, Mazhar Iqbal Khaskheli ${ }^{4}$, \\ Nazir Ahmed Brohi ${ }^{5}$ and Saeed Akhtar Abro ${ }^{6}$ \\ ${ }^{1}$ Dr. M. A. Kazi Institute of Chemistry, University of Sindh, Jamshoro, Pakistan. \\ ${ }^{2}$ National Center of Excellence in Analytical Chemistry, University of Sindh, Jamshoro, Pakistan. \\ ${ }^{3}$ Institute of Advanced Research Studies in Chemical Sciences, University of Sindh, Jamshoro, Pakistan. \\ ${ }^{4}$ Department of Chemistry, Government College University, Kali Mori Hyderabad, Sindh, Pakistan. \\ ${ }^{5}$ Department of Microbiology, University of Sindh, Jamshoro, Pakistan. \\ ${ }^{6}$ Institute of Plant Science, University of Sindh, Jamshoro, Pakistan. \\ *Corresponding Author Email: zahid_zounr100@yahoo.com \\ Received 10 November 2020, Revised 05 March 2021, Accepted 10 March 2021
}

\begin{abstract}
An easy, sensitive and accurate spectrophotometric method has been developed for the determination of Lisinopril (LNP) in pure and tablet formulations based on derivatization reaction with 2-hydroxynaphthaldehyde (2HNA). The derivatization reaction was carried out in methanol solvent at $\mathrm{pH}-5.5$ at $95 \pm 2^{\circ} \mathrm{C}$ for $15 \mathrm{~min}$. The linear calibration curve was obtained that obeyed the Beer's law within the concentration range $5-50 \mu \mathrm{gmL}^{-1}$ of LNP at $433 \mathrm{~nm}$ with a coefficient of determination $\mathrm{R}^{2}=0.996$. The recovery was in the range from $98.25-101.82$ with molar absorptivity of drug $9 \times 10^{3} \mathrm{~mole}^{-1} \mathrm{~cm}^{-1}$. The method was accurate and precise (intra-day variation $0.05-0.97 \%$ and inter-day $0.07-1.6 \%$ ), with limit of detection (LOD) and limit of quantification (LOQ) 0.264 $\mu \mathrm{gmL}^{-1}$ and $0.8 \mu \mathrm{gmL}^{-1}$, respectively. No interferences from the excipients were detected. The method was applied for the rapid analysis of LNP in pharmaceutical products.
\end{abstract}

Keywords: Lisinopril, Spectrophotometry, 2-hydroxynaphthaldehyde, Derivatization

\section{Introduction}

Lisinopril 1-[6-Amino-2-(1-carboxy-3-phenylpropylamino)-hexanoyl]-pyrrolidine-2 carboxylic acid. It has a molecular formula of $\mathrm{C}_{21} \mathrm{H}_{31} \mathrm{~N}_{3} \mathrm{O}_{5}$ and a molecular weight of $441.52 \mathrm{gmol}^{-1}[1-3]$. The structure of drug LNP \& reagent 2HNA are given below (Fig.1).

LNP, is the third ACE inhibitor permitted for use in the United States; LNP itself is active, unlike enalaprilat (ENA). LNP is a significantly more potent inhibitor of ACE than enalaprilat in vitro. Both are used for heart failure and hypertension treatment and diuretic medications. LNP is an angiotensin converting enzyme inhibitor used in the medication of hypertension and heart failure in prophylactic treatment following myocardial infarction and diabetic nephropathy. LNP are amongst the key therapeutic developments of modern medicine due to their histrionic impact in the treatment of congestive cardiac failure and arterial hypertension. The renin-angiotensin system is instantaneously stimulated as a reflex response in order to conserve blood volume. 


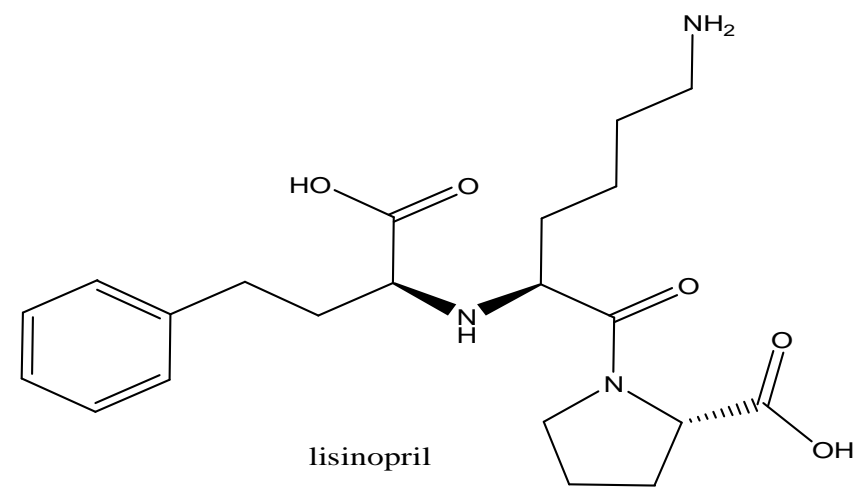

Figure 1. Structure of drug lisinopril \& reagent 2-hydroxynaphthaldehyde

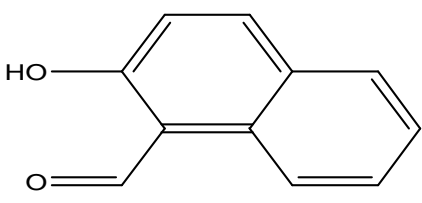

2hydroxynaphthaldehyde
The LNP causes blood pressure reduction by $5-6 \mathrm{~mm} \mathrm{Hg}$, due to which $40 \%$ hazard of stroke and 15-20\% coronary heart disease can be decreased. Various classes of allopathic drugs such as diuretics, antagonists of adrenergic receptors, adrenergic agonists, blockers of calcium channels, ACE inhibitors, antagonists of angiotensin II receptors, antagonists of aldosterone, vasodilators and centrally acting adrenergic drugs are used in the maintenance and treatment of all types of hypertension [4].

It has been observed that in some cases, sub-standard medicinal drugs which do not contain the amount of active ingredient stated on the label are sold in the market. This has prompted the quality control labs to do random sampling of the marketed drugs and determine the active ingredient content for quality control purpose. In developing countries, the quality control labs do not have expensive, sophisticated equipment to embark upon the drug quality control task.

The literature reveals various analytical methods were described for the determination of LNP such as titrimetric [5, 6], Spectrophotometric [7-15], spectrofluorometric [16-20], chromatographic [21-38], derivative UV-spectrophotometric, [39-40] polarography [41-42], radioimmunoassay [43] and fluoroimmunoassay [44].
Spectroscopy is still the most widely used analytical tool for major qualitative and quantitative analysis of pharmaceutical formulations. It delivers key financial and experimental advantages over other techniques. For example, many derivative spectrophotometric methods were established using different reagents, one of them Paraskevas and co-workers developed a spectrophotometric method [12] in single and multi-component tablets also containing hydrochlorothiazide (HCT), based on the derivatization reaction with 1-fluoro-2,4dinitrobenzene (FDNB, Sanger reagent). The active ingredient contents of drug in pure and dosage form were determined, using acetonitrile solvent, at $\mathrm{pH} 8.2$ (borate buffer) in the dark at $60{ }^{\circ} \mathrm{C}$ for $45 \mathrm{~min}$. The LNP complex was measured at $\lambda_{\max } 356.5$ or $405.5 \mathrm{~nm}$ (only at $405.5 \mathrm{~nm}$ if HCT is present).

Another method was proposed by Sbârcea [45] and her team for the quantitative determination of LNP in bulk and pharmaceutical formulations based on the reaction with ninhydrin in the presence of potassium hydroxide. The reaction quantitatively proceeds at a temperature of 95 $\pm 2^{\circ} \mathrm{C}$, in $10 \mathrm{~min}$ and the end product, purple colored, exhibits maximum absorption at 567 $\mathrm{nm}$. 


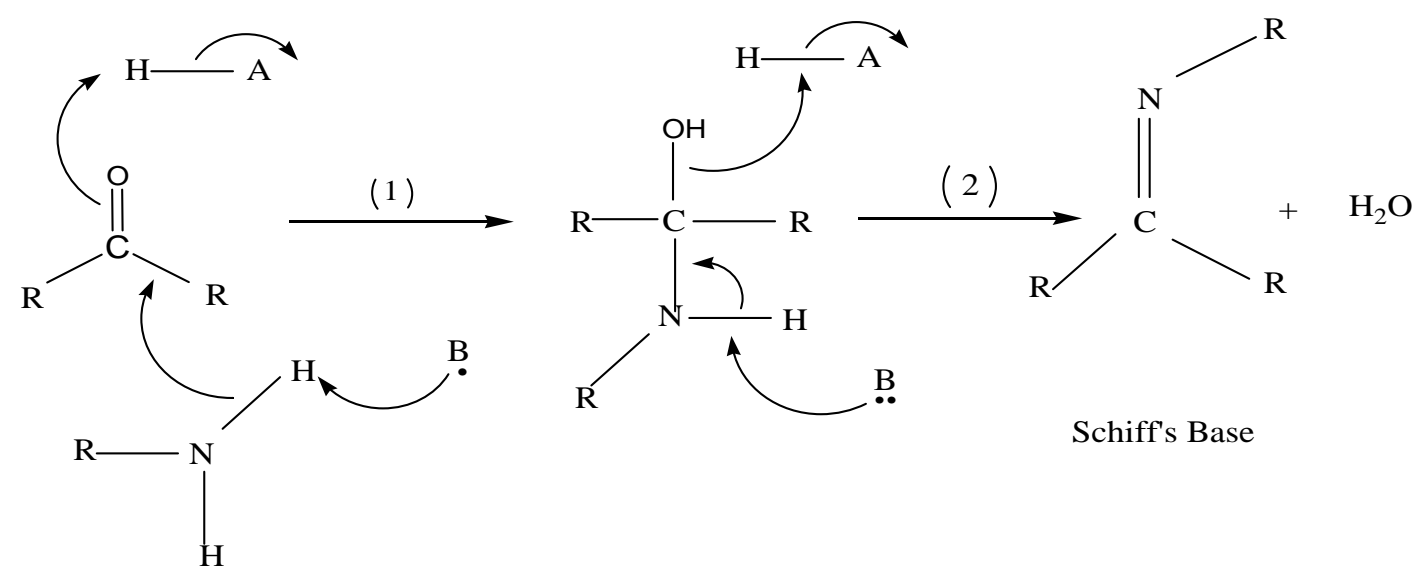

Scheme 1. Principle of reaction (schiff's base reaction)

Finally, the latest method was developed by Shraitah [46] based on the reaction of Alizarin with primary amine present in the LNP in the presence of $80 \%$ ethyl alcohol. The reaction produced a complex red colored product that absorbs maximally at $434 \mathrm{~nm}$. The above reported methods were not only time consuming but also involve expensive solvents, and thus hard to apply in routine analysis. This prompted us to develop a simple, economical and rapid spectrophotometric procedure to determine LNP from pure and drug formulations. The process is based on Schiff base reaction by an aldehyde or ketones reacting with a primary amino group under acid or base catalysis or heat. In the same way, amino group of LNP reacts with the aldehyde group of 2HNA reagent. The following general reaction is shown in scheme 1 .

\section{Materials and Methods Reagents and Chemicals}

All of the materials and reagents used were of analytical grade. LNP (100.21\%) was obtained from Bosch Pharmaceutical (Pvt.) Ltd. The reagent 2HNA (100.1\%) was purchased from EMD Chemicals (Gibbstown, NJ, USA), acetic acid, potassium chloride, hydrochloric acid, sodium carbonate, sodium bicarbonate, methanol, ethanol were from
Merck, Germany. Sodium acetate was from Fluka, Switzerland. De-ionized water was used throughout the study.

\section{Commercial Tablets}

Tablets CORACE (Bosch Pharmaceutical Pvt. Ltd.), ZESTRIL (ICI Pakistan Ltd.), TRUPRIL (Getz Pharma Pakistan), which obtained labeled amount of $10 \mathrm{mg} / \mathrm{tablet}$, while LISNA (ZAFA Pharmaceutical Lab. Pakistan) contained 20 $\mathrm{mg} /$ tablet LNP and purchased from local market Hyderabad, Sindh, Pakistan.

\section{Stock Solutions \\ Standard solutions}

The stock solution $(0.02 \% \mathrm{w} / \mathrm{v})$ of drug LNP was prepared by dissolving exact weighed $20 \mathrm{mg}$ in $10 \mathrm{~mL}$ volumetric flask in methanol. Then $1 \mathrm{~mL}$ above solution diluted up to $10 \mathrm{~mL}$ calibrated volumetric flask in the same solvent. The stock solution $(1 \% \mathrm{w} / \mathrm{v})$ of reagent 2HNA was freshly prepared by dissolving $0.1 \mathrm{gm}$ in sufficient methanol and the volume was adjusted to $10 \mathrm{~mL}$, achieving $10 \mathrm{mgmL}^{-1}$ concentrations.

\section{Buffer solutions}

The buffer solutions were prepared of pH $1-2$ by utilizing $(0.1 \mathrm{M})$ hydrochloric acid and $(0.1 \mathrm{M})$ potassium chloride, $\mathrm{pH}$ 3-5.7 
$(0.1 \mathrm{M})$ acetic acid and $(0.1 \mathrm{M})$ sodium acetate, pH 5.8-8 sodium phosphate monobasic and sodium phosphate dibasic, $\mathrm{pH}$ 8-10 sodium carbonate and sodium bicarbonate.

\section{Instrumentation}

All measurements were performed using the Perkin Elmer double beam spectrophotometer,Lambda 35 UV/Visible spe ctrometer (USA), connected to Dell computer, using $1 \mathrm{~cm}$ quartz cuvette, and the $\mathrm{pH}$ meter was used by model Orion 420A pH meter fitted with a glass electrode and reference electrode (Orion Research Inc. Boston, USA).

\section{Method-1}

\section{Analysis of standard drug LNP}

The LNP drug solutions 1-5 mL were dissolved in methanol at concentrations 5-50 $\mu \mathrm{gmL}^{-1}$, and $1 \mathrm{~mL}$ of each drug solution was transferred to $10 \mathrm{~mL}$ calibrated volumetric flask, followed by the addition of $2 \mathrm{~mL}$ of reagent $2 \mathrm{HNA}(1 \% \mathrm{w} / \mathrm{v})$ prepared in methanol and $1 \mathrm{~mL}$ alcoholic acetate buffer $\mathrm{pH}-5.5$. The mixture was heated for $15 \mathrm{~min}$ at $95{ }^{\circ} \mathrm{C} \pm 1{ }^{\circ} \mathrm{C}$ on a water bath. Then flask contents were allowed at room temperature and the volume was adjusted with methanol up to the mark. The absorbance was finally measured at $433 \mathrm{~nm}$ against the blank.

\section{Method-2}

\section{Application on analysis of commercial tablets}

An accurately weighed mass of 20 tablets was crushed. The powder of tablets equivalent to $20 \mathrm{mg}$ LNP was weighed and transferred into a $100 \mathrm{~mL}$ volumetric flask containing a sufficient amount of solvent methanol. The suspension was stirred for 10 min. The solution was filtered through a filter paper (Whatman No. 1), after rinsing with methanol the volume was adjusted to $100 \mathrm{~mL}$. Then $1 \mathrm{~mL}$ of the resulting solution was shifted to $10 \mathrm{~mL}$ stoppered volumetric flask, and $2 \mathrm{~mL}$ of reagent 2HNA was added, followed by $1 \mathrm{~mL}$ acetate buffer $\mathrm{pH}-5.5$. The contents were heated up to $15 \mathrm{~min}$ at $95^{\circ} \mathrm{C} \pm$ $1{ }^{\circ} \mathrm{C}$ on a water bath, cooled at room temperature $\left(25^{\circ} \mathrm{C}\right)$, the volume was adjusted and absorbance recorded at $433 \mathrm{~nm}$, against the blank.

\section{Validation of method for derivatization}

A newly developed spectrophotometric method for the determination of imine derivative of LNP was validated for linearity, accuracy, \% recovery, sensitivity, precision and stability of solutions.

\section{Linearity}

For calibration and linearity, five different concentrations of the imine derivative were used in the range of 5-50 $\mu \mathrm{gmL}^{-1}$. The linearity of the method was determined by plotting the absorbance versus concentration of drug LNP derivative. The slope $(\mathrm{m})$, intercept (b), and the correlation coefficient $\left(\mathrm{R}^{2}\right)$ were determined from the regression analysis.

\section{Percent recovery measurement}

The $\%$ recovery was calculated by added pure drug LNP with 2HNA derivative solution as \% recovery $=\left[\left(\mathrm{D}_{\mathrm{t}}-\mathrm{D}_{\mathrm{s}}\right) / \mathrm{D}_{\mathrm{a}}\right] \times$ 100 where $D_{t}$ is the total drug concentration after standard addition; $D_{s}$ is the drug concentration in the imine derivative mixture and $\mathrm{D}_{\mathrm{a}}$ is the drug concentration added.

\section{Sensitivity}

The sensitivity of the proposed method was calculated by a limit of detection (LOD) and lower limit of quantification (LOQ) of imine derivative using signal to noise ratio $(\sigma / \mathrm{s})$ of $3.3 \sigma / \mathrm{s}$ and $10 \sigma / \mathrm{s}$, respectively; 
where $\sigma$ is the standard deviation of the signal and $\mathrm{s}$ is the slope of a corresponding calibration curve.

\section{Precision}

The imine derivative solution was analyzed at three intervals a day at 08:00, 16:00, 24:00, h for repeatability and for three consecutive days for reproducibility in order to assess the intermediate precision (intra-day and inter-day). The outcome was expressed as

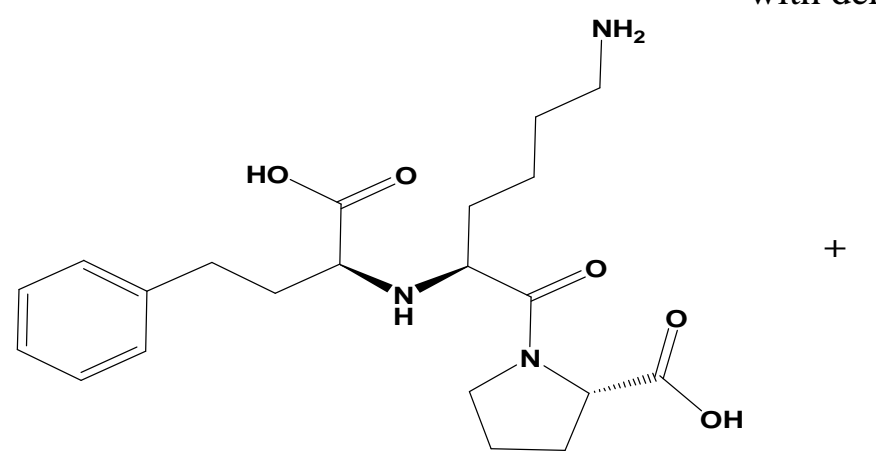

the mean \pm SD and percent relative standard deviation (\%RSD).

\section{Results and Discussion}

The motive of this research work was to develop a simple approach for the determination of LNP in pure and pharmaceutical formulations. Scheme 2 illustrates the reaction mechanism of preparation of new imine derivative LNP2HNA by primary amino group of LNP drug with derivatizing reagent 2 HNA.

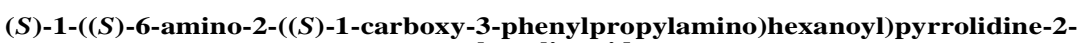

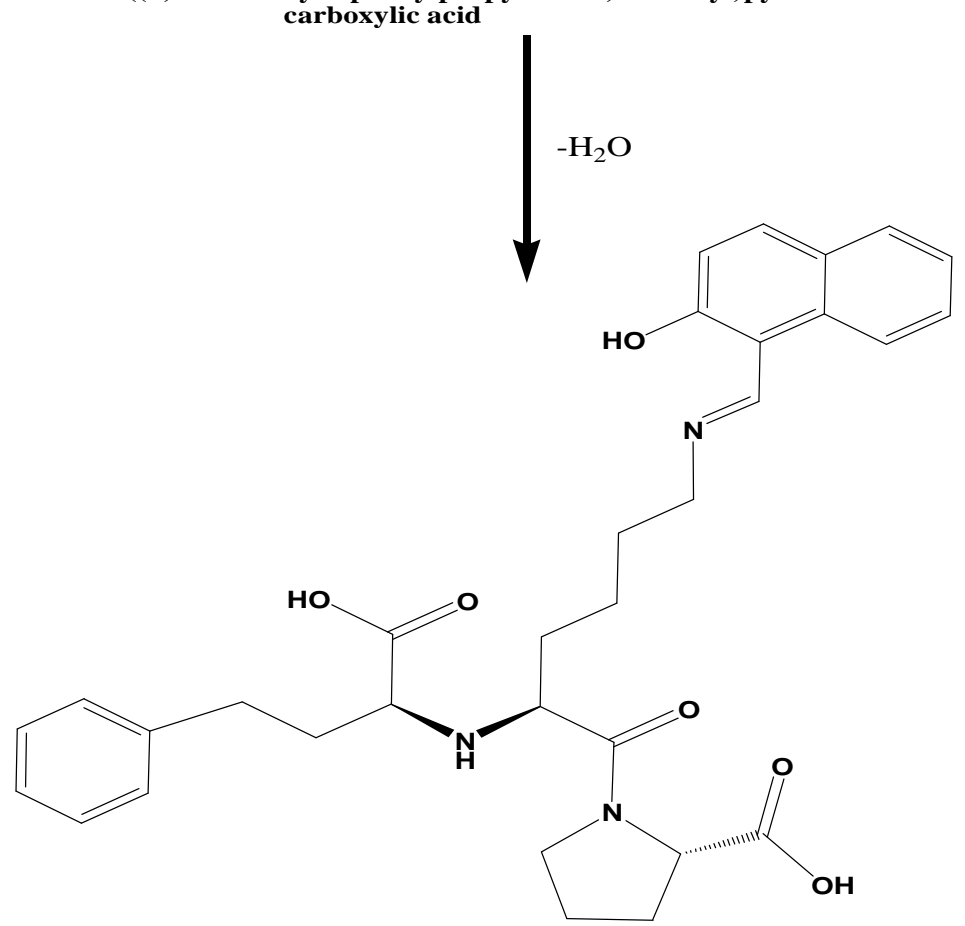

$(S)$-1-((S)-2-((S)-1-carboxy-3-phenylpropylamino)-6-((E)-(2-hydroxynaphthalen-1-yl)methyleneamino)hexanoyl)pyrrolidine-2carboxylic acid 
The 2HNA was used as a derivatizing reagent for the colorimetric analysis of LNP. The reagent 2HNA reacted with the drug LNP to produce imine derivative LNP-2HNA having a light yellow color. This reaction took place in the acid medium at $\mathrm{pH}-5.5$ with maximum absorbance at $\left(\lambda_{\max }\right) 433 \mathrm{~nm}$, molar absorptivity of $9 \times 10^{3} \mathrm{~mole}^{-1} \mathrm{~cm}^{-1}$. The specific parameters were optimized, which effect the preparation of the 2HNA-LNP derivative similarly effect of reagent quantity, $\mathrm{pH}$, heating time and temperature.

\section{Analytical Parameters Optimization Selection of wavelength}

The wavelength of maximum absorbance shows a vital role for quantitative determinations. It is crucial to choose the wavelength where the derivative gives optimal absorbance. The absorbance of $20 \mu \mathrm{gmL}^{-1}$ of LNP and 2HNA derivative was measured within the range of $350-500 \mathrm{~nm}$. The $\left(\lambda_{\max }\right)$ is optimized in the visible range at $433 \mathrm{~nm}$ against a reference.

\section{Selection of optimal temperature and heating time for the preparation of derivative}

Initially, it was observed that the rate of reaction was very slow at room temperature, therefore the mixture contents were heated and the derivatization reaction was monitored on the optimal wavelength $\left(\lambda_{\max }\right) 433 \mathrm{~nm}$ for 0-30 min with an interval of 5 min at $95{ }^{\circ} \mathrm{C}$.

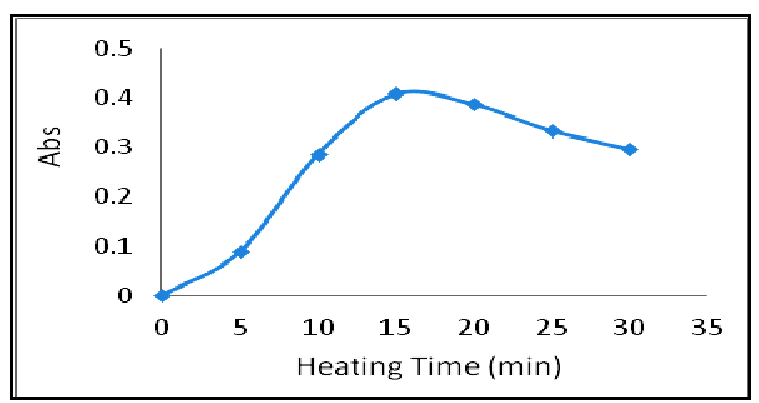

Figure 2. Effect of temperature to the yield of reaction
It was observed that the best derivatization occurred by heating the reaction mixture for $15 \mathrm{~min}$ at $95^{\circ} \mathrm{C} \pm 1^{\circ} \mathrm{C}$ (Fig. 2).

\section{Optimization volume and concentration of reagent}

The effect of adding different quantities of reagent $2 \mathrm{HNA}$ solution to $1 \mathrm{~mL}$ of drug LNP $(0.02 \% \mathrm{w} / \mathrm{v})$ was also studied. The reagent concentration of $(1 \% \mathrm{w} / \mathrm{v}) 2 \mathrm{HNA}$ was varied between $0.5-3.0 \mathrm{~mL}$ in the $10 \mathrm{~mL}$ volumetric flask containing $1 \mathrm{~mL}$ of drug LNP. There was no change in rising absorbance noticed after the addition of $2 \mathrm{~mL}$ reagent. Therefore, the best absorbance was measured by adding $2 \mathrm{~mL}$ of reagent $2 \mathrm{HNA}$ as shown in Fig. 3.

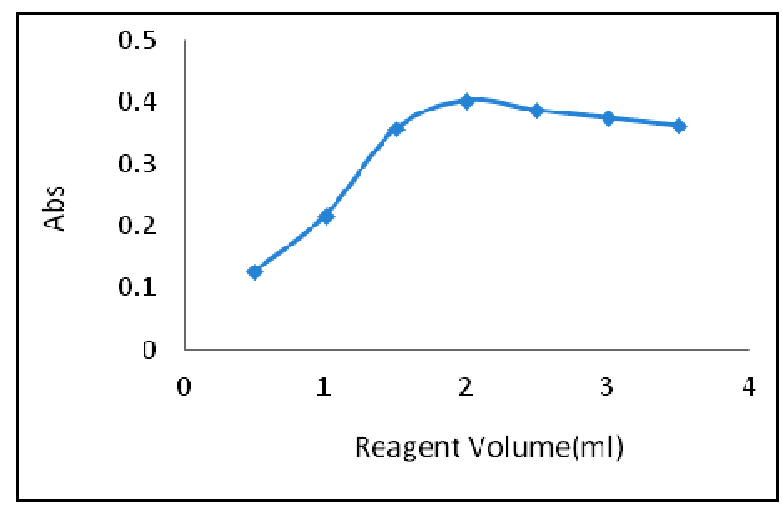

Figure 3. Effect of reagent $2 \mathrm{HNA}$ concentration on color development

\section{pH effect on derivative}

At the most optimal conditions, the effect of adding $1 \mathrm{~mL}$ of $0.1 \mathrm{M}$ different buffer solutions at $\mathrm{pH}$ ranges 2-10 was studied on the derivative. The consistent increase in absorbance was examined from $\mathrm{pH}$ 4-6. Further $\mathrm{pH}$ was specified by using buffer solution at a difference of 0.5 like $\mathrm{pH} 5.0,5.5$, 6.0 , etc. The best maximum absorbance was obtained utilizing acetate buffer solution at $\mathrm{pH}$ 5.5 (Fig. 4). The addition of other buffers $\mathrm{pH}$ 8-10 revealed precipitation. Thus acetate buffer pH 5.5 was considered as optimal. 


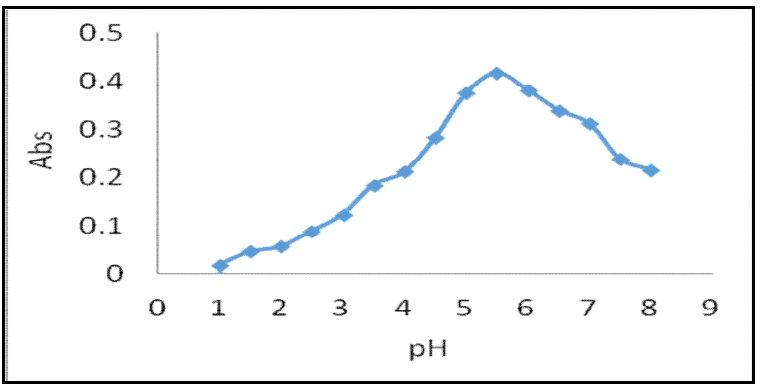

Figure 4. Effect of pH on derivative color intensity

\section{Effect of solvent}

The effect of solvents on derivative was investigated by the addition of $2 \mathrm{~mL}$ of mentioned solvent and compared with $2 \mathrm{~mL}$ methanol. The procedure of determining solvent effect explained that the mixture contents containing $1 \mathrm{~mL}$ of drug LNP $(0.02 \%$ w/v), $2 \mathrm{~mL}$ reagent $2 \mathrm{HNA}(1 \% \mathrm{w} / \mathrm{v})$ and $1 \mathrm{~mL}$ acetate buffer $\mathrm{pH}-5.5$, were heated for 15 minutes, then cooled same at room temperature $25{ }^{\circ} \mathrm{C}$, then $2 \mathrm{~mL}$ of following mentioned solvents were added in $10 \mathrm{~mL}$ volumetric flask and in the blank. It was observed that none of the following solvents interfered in the LNP-2HNA derivative (Table 1).

Table 1. Effect of solvents on derivative in terms of maximum absorbance.

\begin{tabular}{lccc}
\hline Solvent & $\begin{array}{c}\text { Volume } \\
(\mathbf{m L}) \\
\text { added }\end{array}$ & $\begin{array}{c}\text { Abs. with } \\
\text { methanol }\end{array}$ & $\begin{array}{c}\text { Abs. with other } \\
\text { solvents }\end{array}$ \\
\hline THF & 2 & 0.422 & 0.425 \\
derivative & $\begin{array}{c}\text { LNP-2HNA } \\
\text { derivative }\end{array}$ \\
Acetone & 2 & 0.424 & 0.426 \\
n-Hexane & 2 & 0.421 & 0.418 \\
Ethyl acetate & 2 & 0.423 & 0.420 \\
Isopropanol & 2 & 0.418 & 0.418 \\
Acetonitrile & 2 & 0.425 & 0.421 \\
Propanol & 2 & 0.423 & 0.420 \\
Butanol & 2 & 0.422 & 0.425 \\
\hline
\end{tabular}

\section{Effect of mixing order of reagents}

Various mixing orders in the current work were applied. The absorbance decreased when mixed $1 \mathrm{~mL}$ acetate buffer $\mathrm{pH}-5.5$ in drug LNP $(0.02 \% \mathrm{w} / \mathrm{v})$, then reagent $2 \mathrm{HNA}$ $(1 \% \mathrm{w} / \mathrm{v})$. Altering the sequence of mixing by adding 2HNA first, then buffer followed by LNP solution also has revealed little amount of absorbance. It was confirmed that the addition of $1 \mathrm{ml}$ of drug LNP drug first, then 2 $\mathrm{mL}$ reagent $2 \mathrm{HNA}$ followed by $1 \mathrm{~mL}$ buffer $\mathrm{pH}-5.5$ solution provided maximum absorbance of derivative.

\section{Effect of additives}

The effect of the possible presence of additives like calcium hydrogen phosphate, maize starch, mannitol, pregelantised maize starch, magnesium stearate on absorbance in the determination of drug LNP was studied. Two concentration levels, first at an equal concentration of the drug $\operatorname{LNP}(0.02 \% \mathrm{w} / \mathrm{v})$, and second at 10 times the concentration of drug, did not change the absorbance significantly. Not more than $\pm 2 \%$ change in absorbance was calculated and no any additive interfered in the derivative LNP-2HNA during the determination of LNP drug (Table 2).

Table 2. Effect of additives on absorption of derivative.

\begin{tabular}{lccc}
\hline \multicolumn{1}{c}{ Additive } & $\begin{array}{c}\text { Abs. without } \\
\text { additives } \\
\text { (LNP-2HNA) } \\
\text { Derivative }\end{array}$ & $\begin{array}{c}\text { Abs. with additives } \\
\text { (LNP-2HNA) } \\
\text { Derivative }\end{array}$ \\
\cline { 3 - 4 } & 0.420 & $\begin{array}{c}\text { Equal } \\
\text { conc. to } \\
\text { drug }\end{array}$ & $\begin{array}{c}\text { 10x Conc. } \\
\text { to drug }\end{array}$ \\
\hline $\begin{array}{l}\text { Calcium hydrogen } \\
\text { phosphate }\end{array}$ & 0.421 & 0.424 & 0.423 \\
$\begin{array}{l}\text { Maize starch } \\
\text { Mannitol }\end{array}$ & 0.422 & 0.418 & 0.419 \\
$\begin{array}{l}\text { Pregelantised } \\
\text { maize starch } \\
\begin{array}{l}\text { Magnesium } \\
\text { stearate }\end{array}\end{array}$ & 0.423 & 0.420 & 0.418 \\
\hline
\end{tabular}

\section{Percent recovery from dosage form}

Table 3 shows the percentage recovery of LNP-2HNA derivative from four different commercial drugs by above 
mentioned method (2). The percentage recovery was found more than $98 \%$ in all particular formulations.

Table 3. Application of proposed method on commercial drugs.

\begin{tabular}{cccc}
\hline $\begin{array}{c}\text { Drug } \\
\text { Brands }\end{array}$ & $\begin{array}{c}\text { Labeled } \\
\text { amount per } \\
\text { tablet (mg) }\end{array}$ & $\begin{array}{c}\text { Amount found } \\
\text { per tablet }\end{array}$ & $\begin{array}{c}\text { \% } \\
\text { Recovery }\end{array}$ \\
\hline Corace & 10 & 9.81 & 98.1 \\
Zestril & 10 & 10.06 & 100.6 \\
Trupil & 10 & 9.93 & 99.3 \\
Lisna & 20 & 19.87 & 99.3 \\
\hline
\end{tabular}

\section{Stability of derivative}

The stability of LNP-2HNA derivative was analyzed in terms of absorbance at the concentration of $20 \mu \mathrm{gmL}^{-1} \mathrm{LNP}$. There was no significant change in absorbance was evaluated within $48 \mathrm{~h}$.

\section{Calibration graph (Beer's Law)}

A linear calibration curve (Fig. 5) regarding the correlation between absorbance and different concentrations of the drug LNP was depicting linearity within the concentration range 5-50 $\mu \mathrm{gmL}^{-1}$ of LNP with 2HNA, and correlation coefficient of $99.96 \%$ $\left(\mathrm{R}^{2}=0.9996\right)$.

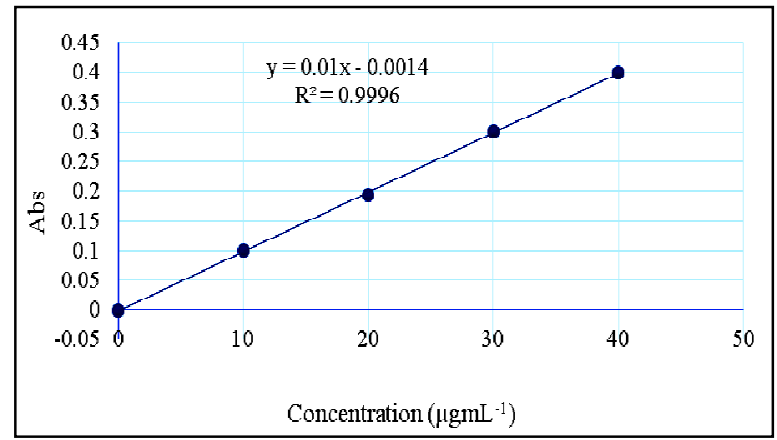

Figure 5. Linearity curve of spectrophotometric determination

\section{Reproducibility /repeatability}

For the stability of derivative, the assessment of interday and intraday repeatability of the procedure is an important parameter. The methanolic solution of LNP 20 $\mu \mathrm{gmL}^{-1}$ was taken in three separate $(10 \mathrm{~mL})$ calibrated flasks and the method was applied as mentioned method (1). The method was repeated for three days $(n=3)$. The average mean absorbance of intraday and interday reproducibility for imine derivative was seen as $0.264 \mu \mathrm{gmL}^{-1}$ and $0.8 \mu \mathrm{gmL}^{-1}$ with (RSD) values $0.97 \%$ and $1.6 \%$, respectively (Table 4).

Table 4. Sensitivity comparison of proposed method for imine derivative with $\mathrm{AB}$.

\begin{tabular}{cccc}
\hline Parameters & Imine & $\begin{array}{c}\text { LNP } \\
\text { drug }\end{array}$ \\
\hline $\begin{array}{c}\text { Precision } \\
(\mathrm{n}=3)\end{array}$ & $\begin{array}{c}\text { Inter-day } \\
\text { Intra-day }\end{array}$ & 0.264 & - \\
$\begin{array}{c}\text { Sensitivity } \\
\left(\mu \mathrm{gmL}^{-1}\right)\end{array}$ & $\begin{array}{c}\text { Limit of detection } \\
(\text { LOD) }\end{array}$ & 0.801 & 1.77 \\
& $\begin{array}{c}\text { Limit of } \\
\text { quantification } \\
\text { (LOQ) }\end{array}$ & 1.60 & 3.97 \\
\hline
\end{tabular}

\section{Validation of the proposed method}

Statistical evaluations for linearity, sensitivity, percentage recovery, precision, LOD and LOQ of the proposed method were given in (Table 5). The comparative study of our developed method with previous reported spectrophotometric methods given in (Table 6), that reveals the LOD and LOQ values were smaller over other mentioned reported methods.

Table 5. Statistical evaluations of the developed method.

\begin{tabular}{ll}
\hline Parameters & Observation \\
\hline Derivative color & Light yellow \\
Absorption maxima $(\mathrm{nm})$ & 433 \\
Linearity range $(\mu \mathrm{g} / \mathrm{mL})$ & $5.0-50.0$ \\
Molar absorptivity $\left.(\mathrm{L} \mathrm{Mol})^{-1} \mathrm{~cm}^{-1}\right)$ & $0.910^{4}$ \\
Sandell sensitivity $\left(\mu \mathrm{g} / \mathrm{cm}^{2} / 0.001\right.$ abs unit) & $5.9 \times 10^{-2}$ \\
Correlation coefficient $\left(\mathrm{R}^{2}\right)$ & 0.996 \\
$\mathrm{RSD}(\%)$ & 0.775 \\
Slope $(\mathrm{b})$ & 0.01 \\
Intercept $(\mathrm{a})$ & 0.0014 \\
Percentage of recovery $(\%)$ & $98.74-99.52$ \\
Limit of detection $(\mathrm{LOD}) \mu \mathrm{gg} / \mathrm{mL}$ & 0.264 \\
Limit of quantification $(\mathrm{LOQ}) \mu \mathrm{g} / \mathrm{mL}$ & 0.8 \\
Intra-day variation $(\%)$ & $0.05-0.97$ \\
Inter-day variation $(\%)$ & $0.07-1.60$ \\
\hline
\end{tabular}


Table 6. Comparison of proposed methods with existing spectrophotometric methods for the assay of LNP in pharmaceutical formulations.

\begin{tabular}{|c|c|c|c|c|c|c|}
\hline $\begin{array}{l}\text { Derivatizing } \\
\text { reagent }\end{array}$ & $\begin{array}{l}\lambda_{\max } \\
(\mathbf{n m})\end{array}$ & $\begin{array}{l}\text { Reaction } \\
\text { Time } \\
\text { (min/temp) }\end{array}$ & $\begin{array}{l}\text { LOD } \\
\left(\mu \mathrm{g} \mathrm{mL}^{-1}\right)\end{array}$ & $\begin{array}{l}\text { LOQ } \\
\left(\mu \mathrm{g} \mathrm{mL} \mathbf{L}^{-1}\right)\end{array}$ & $\begin{array}{l}\text { Linear range } \\
\left(\mu \mathrm{g} \mathrm{mL}^{-1}\right)\end{array}$ & References \\
\hline $\begin{array}{l}\text { 1,2-naphthoquinone-4- } \\
\text { sulfonic (NQS) }\end{array}$ & 481 & $5 / 25^{\circ} \mathrm{C}$ & 1.16 & 3.53 & $5-50$ & [9] \\
\hline Alizarin & 434 & $7 / 40^{\circ} \mathrm{C}$ & 2.08 & 6.94 & $4-300$ & [46] \\
\hline Ninhydrin & 600 & $5 / 80^{\circ} \mathrm{C}$ & 5.587 & 18.437 & $10-150$ & [47] \\
\hline Phenylhydraizine & 362 & $20 / 85^{\circ} \mathrm{C}$ & - & - & $40-200$ & [48] \\
\hline Ascorbic acid & 530 & $15 / 100^{\circ} \mathrm{C}$ & 0.349 & 1.152 & $5-50$ & [49] \\
\hline Chloranil & 346 & - & - & - & $4-20$ & [50] \\
\hline $\begin{array}{l}\text { 2-hydroxynaphthaldehyde } \\
\text { (2HNA) }\end{array}$ & 433 & $15 / 95^{\circ} \mathrm{C}$ & 0.264 & 0.8 & $5-50$ & Current work \\
\hline
\end{tabular}

\section{Precision}

Four drug formulations were being repeatedly analyzed in three successive days in order to evaluate intra-day and interday reproducibility for imine derivative was seen at $0.07 \%$ and $1.6 \%$, respectively. The $\%$ RSD values lower than $2 \%$ were obtained in our studies witness that the developed method was precise (Table 5).

\section{Accuracy}

The accuracy of the proposed method has been evaluated by applying the developed method for the determination of LNP in pharmaceutical formulations. The concentration of each drug was determined from the corresponding regression equations. The obtained percentage recoveries indicate the appropriate accuracy of the proposed method. The standard addition method was also carried out to analyze the accuracy of the method. Method accuracy was assessed for the determination of the commercial tablets by adding varying amounts of the standard LNP to a certain concentration of filtrate tablet solution. The findings showed good recoveries with low RSD. Commercial formulations have been successfully analyzed for the proposed Lisinopril method and the results were compared with the reference method [8], (Table 4). The proposed method produces good results in both raw and pharmaceutical formulations (Table 5).

\section{Specificity}

The proposed method was determined successfully for LNP without any interference from tablet excipients, as depicted in Table 2.

\section{Conclusion}

A rapid, simple and economical spectrophotometric method using inexpensive reagents was developed for determination of Lisinopril in pure and tablet form. Our method is robust in terms of reproducibility and high sensitivity. The novelty of this proposed method is to utilize first time 2HNA reagent for derivatization of LNP drug. The LOD and LOQ values are smaller over other spectrophotometric methods reported in the literature. Moreover, the synthesized LNP imine derivative is highly stable.

\section{Acknowledgement}

Authors are thankful to Alkemy Pharmaceutical Laboratories (Pvt.) Ltd. Hyderabad for kindly provide us the drug 
samples. We express our gratitude to Prof. Dr. Shahabuddin Memon, Head of National Centre of Excellence in Analytical Chemistry, for providing laboratory facilities.

\section{Conflict of Interest}

The authors declare that there is no conflict of interest.

\section{References}

1. British Pharmacopoeia Commission, British Pharmaco-poeia 2012, The Stationery Office, Norwich, (2012).

2. United States Pharmacopeia and National Formulary (USP 36-NF 31), United States Pharmacopeia Convention, Rockville, (2012).

3. Society of Japanese Pharmacopoeia, Japanese Pharmacopoeia, 16th ed., Tokyo Maruzen Company Ltd., (2012).

4. L. L. Brunton, J. S. Lazo, \& K. L. Parker, (2006). Goodman \& Gilman. As Bases Farmacológicas da Terapêutica. $11^{\mathrm{a}}$ ed. Rio de Janeiro: Mc Gwaw-Hill Suteramericana do Brasil.

5. A. W. Olalowo, O. M. Adegbolagun, and O. A. Bamiro, African J. Pharm. Pharmacol., 9 (2015) 165.

https://doi.org/10.5897/AJPP2014. 4031

6. K. Basavaiah, K. Tharpa and K. B. Vinay, Eclética Química, 35 (2010) 7. https://doi.org/10.1590/S010046702010000200001

7. A. G. Memon, Pak. J. Anal. Environ. Chem., 21 (2020) 27. http://doi.org/10.21743/pjaec/2020.06 .04

8. V. M. Sarma, N. V. S. Venugopal, and L. Giribabu, Am. J. Anal. Chem., 11 (2020) 289. http://doi.org/10.4236/ajac.2020.118023

9. A. A. A. Ali and A. A. Elbashir, Ame. Acad. Schol. Res. J., 5 (2013) 106.
10. C. M. Jamakhandi, C. Javali, I. J. Disouza, S. U. Chougule and K. A. Mullani, Int. J. Pharm. Sci., 3 (2011) 185.

11. S.Naveed, Mod. Chem. Appl., 2 (2014) 2 http://dx.doi.org/10.4172/2329$\underline{6798.1000137}$

12. G. Paraskevas J. Pharm. Biomed. Anal., 29 (2002) 865.

https://doi.org/10.1016/S07317085(02)00207-8

13. S. A. Shama, A. S. Amin, H. Omara, $J$. Chil. Chem. Soc., 56 (2011) 566. http://dx.doi.org/10.4067/S071797072011000100009

14. F. F. Mohammed, K. Badr El-Din and S. M. Derayea, J. Adv. Biomed. Pharm., Sci., 2 (2019) 47.

http://doi.org/10.21608/JABPS.2019.676 $\underline{6.1031}$

15. Z. Zaheer, S. Khan, M. Sadeque, M. S. Baig and J. N. Sangshetti, J. Indian Assoc. Pediatr. Surg., 1 (2016) 12.

16. S. M. Derayea, K. M. Badr El- Din, F. F. Mohammed. Luminescence, 32 (2017) 1482.

https://doi.org/10.1002/bio.3348

17. S. M. Derayea, K. M. B. El-din and F. F. Mohammed, Spectrochim. Acta Part A, 188 (2018) 318.

https://doi.org/10.1016/j.saa.2017.07.021

18. M. Sobhy, M. E. H. El-Sadek and N. M. Saeed, J. Pharm. Pharm. Res., 2 (2018) 1.

http://doi.org/10.26502/jppr.0005

19. C. M. Jamakhandi, C. Javali, S. Kumar, S. Kumar and S. D. S. Kumar, Int. J. Pharm. Sci. Drug Res., 2 (2010) 182. https://innovareacademics.in/journal/ijpp s/Vol2Suppl4/899. 
20. C. K. Zacharis, P. D. Tzanavaras, D. G. Themelis, G. A. Theodoridis, A. Economou and P. G. Rigas, Anal. Bioanal. Chem., 379 (2004) 759. http://doi.org/10.1007/s00216-004-2530-4

21. K. M. Fahelelbom, M. M. Al-Tabakha, N. A. Eissa, D. E. E. Obaid and S. Sayed, Res. J. Pharm. Technol., 13 (2020) 2647. http://doi.org/10.5958/0974360X.2020.00470.9

22. M. S. Arayne, N. Sultana, A. Tabassum, S. N. Ali and S. Naveed, Med. Chem. Res., 21 (2012) 4542. http://doi.org/10.1002/cjoc.201190226

23. F. Elsebaei and Y. Zhu, Talanta, 85 (2011) 123.

http://doi.org/10.1016/j.talanta.2011.03.037

24. Y. Z. Fawzi Elsebaeia. Talanta, 85 (2011) 123.

http://doi.org/10.1016/j.talanta.2011.03.037

25. N. S. Goud, G. Achaiah, V. Sivaramakrishna and P. Mayuri, Int. J. Pharm. Tech. Res., 8 (2015) 448.

https://www.scholarsresearchlibrary.com $\underline{\text { articles }}$

26. V. Kumar, R. P. Shah and S. Singh, J. Pharm. Biom. Anal., 47 (2008) 508. http://doi.org/10.1016/j.jpba.2008.01.041

27. Y. Latha and D. G. Sankar, Asian J. Res. Chem., 8 (2015) 27.

http://doi.org/10.59558/09744150.2015.00006.1

28. Y. X. Liu, D. Shou, M. L. Chen, Z. D. Chen, P. M. Zhang and Y. Zhu, Chin. Chem. Lett., 23 (2012) 335.

https://doi.org/10.1016/j.cclet.2011.11.024

29. V. Maslarska and J. Tencheva, Int. J. Pharm. Bio. Sci., 4 (2013) 163.

30. J. V. Odovic, B. D. Markovic, R. D. Injac, S. M. Vladimirov and K. D.
Karljikovic-Rajic, J. Chromatogr. A, 1258 (2012) 94.

https://doi.org/10.1016/j.chroma.2012.08 $\underline{.038}$

31. J. J. Pandya, M. Sanyal and P. S. Shrivastav, J. Liq. Chromatogr. Rel. Technol., 19 (2017) 12.

https://doi.org/10.1080/10826076.2017.1 $\underline{324482}$

32. N. M. Rao and D. Gowrisankar Indian J. Pharm. Sci., 78 (2016) 217.

http://doi.org/10.4172/pharmaceuticalsciences.1000106

33. N. Rastkari and R. Ahmadkhaniha, Biomed. Chromatogr., 1 (2017) 10. http://doi.org/10.1002/bmc.4120

34. A. Sana, S. Naveed, F. Qamar, S. Shakeel Pak. J. Pharm. Sci., 30 (2017) 635.

http://doi.org/10.12991/marupj.300842

35. S. Şenkardeş, T. Özaydın, T._Uğurlu and Ş. G. Küçükgüzel, Marmara Pharm. J. 21 (2017) 338. http://doi.org/10.12991/marupj.300842

36. N. Shafi, F. A. Siddiqui, N. Sultana and M. S. Arayne. J. Liq. Chromatogr. Rel. Tech., 38 (2015) 1466. https://doi.org/10.1080/10826076.2015.1 $\underline{050503}$

37. T. B. Stoimenova, M. Piponski, G. T. Serafimovska and M. Stefova, Maced. J. Chem. Chem. Eng., 36 (2017) 201. http://dx.doi.org/10.20450/mjcce.2017.1 $\underline{210}$

38. N. Sultana, S. Naveed and M. Arayne, J. Chromatogr. Separ. Techn., 4 (2013) 1. http://doi.org/DOI: 10.4172/jbb.1000171

39. C. V. N. Prasad, R. N. Saha and P. Parimoo, Pharm. Pharmacol. Commun., 5 (1999) 383. 
https://doi.org/10.1211/14608089912873 $\underline{5027}$

40. N. Erk, Spectroscopy Letters, 31 (1998) 633.

https://doi.org/10.1080/00387019808002756

41. V. K. Redasani, P. R. Patel, D. Y. Marathe, S. R. Chaudhari, A. Shirkhedkar and S. J. Surana, J. Chil. Chem. Soc., 63 (2018) 4126. http://dx.doi.org/10.4067/s071797072018000304126

42. W. Gul, Z. Augustine, S. Khan, K. Saeed and H. Raees, J. Bioequiv. Availab., 9, (2017) 31 .

http://doi.org/10.4172/jbb.1000320

43. P. J. Worland and B. Jarrott, J. Pharm. Sci., 75 (1986) 512 https://doi.org/10.1002/jps.2600750518

44. A. S. Yuan and J. D. Gilbert, J. Pharm. Biomed. Anal., 14 (1996) 773. https://doi.org/10.1016/07317085(95)01718-6
45. L. Sbarcea, L. Udrescu, L. Drăgan, C. Trandafirescu, Z. Szabadai and M. Bojiţă, Farmacia, 62 (2014) 107.

46. M. Shraitah and M. M. Okdeh, Mod. Chem. Appl., 4 (2016) 2.

Doi: 10.4172/2329-6798.1000172

47. A. Raza AND T. M. Ansari, J. Chin. Chem. Soc., 52 (2005) 1055.

https://doi.org/10.1002/jccs.200500149

48. A. El-Gindy, J. Pharm. Biomed. Anal., 25 (2001) 913.

https://doi.org/10.1016/S07317085(01)00376-4

49. N. Rahman, J. Braz. Chem. Soc., 16 (2005) 1001.

https://doi.org/10.1590/S0103$\underline{50532005000600018}$

50. A. F. El-Yazbi, H. H. Abdine, J. Pharm. Biomed. Anal., 19 (1999) 8. https://doi.org/10.1016/S07317085(98)00110-1 